\title{
O necessário zelo pelo meio ambiente
}

Não é preciso ser especialista em ciências ambientais para perceber a importância do meio ambiente para a vida, em sentido amplo, bem como não é preciso muito estudo para notar os avanços das ciências nas mais distintas áreas do conhecimento. A título de curiosidade, a Plataforma Sucupira (s.d., on-line) elenca 49 áreas de conhecimento nas quais os periódicos científicos podem ser classificados, somando-se, entre elas, a área Interdisciplinar, na qual podem ser entrelaçados vários saberes. A rigor, nota-se uma tendência de novas especificidades em confronto com as atuais análises holísticas da interdisciplinaridade.

A exemplo do prólogo acima, constam do site do CNPq, sob o título de Tabela de Áreas do Conhecimento, nada menos que oito grandes áreas, além de uma nona área nomeada como Outros (CNPq, s.d., on-line). As áreas são, na sequência: 1. Exatas e da Terra; 2. Ciências Biológicas; 3. Engenharias; 4. Ciências da Saúde; 5. Ciências Agrárias; 6. Ciências Sociais Aplicadas; 7. Ciências Humanas; 8. Linguística, Letras e Artes; e 9. Outros. Tais áreas se desdobram em 466 subáreas, nas quais as atividades de pesquisa devem se enquadrar quando estiverem sob os auspícios daquela Instituição Federal vinculada ao Ministério da Ciência, Tecnologia, Inovações e Comunicações.

Sobre as tendências atuais, há certo conflito entre o raciocínio dos que desejam aumentar as especificidades da lógica científica e os que pretendem as abordagens holísticas. De certo modo, isso nos remete ao emergir das ciências naturais com Nicolau Copérnico (1473-1543), com Francis Bacon (1626-1626) e o método científico e com o Positivismo de Auguste Comte (1798-1857), em contraposição ao método da especulação filosófica até então predominante. Foi nesse contexto que ganharam merecidamente força as ciências que tratam da natureza e de seus respectivos recursos (CHASSOT, 1994).

Esses avanços do raciocínio científico lembram de perto o que Kuhn (1962) apregoava sobre ciência normal e ciência revolucionária para versar sobre a significação de paradigma. Dissemos isso porque ainda permanece o embate sobre a relevância de um e outro setor do universo científico, 
inclusive sobre a abrangência das ciências voltadas à natureza, em cujo contexto há distintas posições ideológicas, incluindo nisso o usufruto dos recursos renováveis e não renováveis.

Na visão holística e interdisciplinar, toda ação científica tem direta ou indiretamente reflexo sobre o meio ambiente, daí o cuidado que se deve adotar com os procedimentos metodológicos da pesquisa, bem como com os seus resultados. Isso implica entender que o planeta Terra é um sistema fechado, em que os efeitos das ações humanas têm reflexo global. Disso resulta que os cuidados com o meio ambiente devem ser preocupação de todos os segmentos científicos, e não apenas dos que militam de modo específico nessa área. Todavia é preciso ressaltar que a Revista Multitemas vem insistindo na necessária compreensão de que não existe um método único ou melhor de se fazer ciência, isto posto que algumas áreas querem se sobrepor com seus paradigmas em detrimento de outras. Isso pode ser maléfico ao meio ambiente, na medida em que os profissionais afetos a esse modo de ver o mundo não avaliem acertadamente os resultados que seus trabalhos podem, em curto, médio e longo prazo, exercer sobre a natureza.

Em vista do exposto, advoga-se aqui que, seja qual for a tendência, o método, a abordagem e o tipo de pesquisa, deve o pesquisador zelar pelos impactos que pode causar na natureza, os quais, em última instância, resultam em interferência em todo o planeta Terra, diretamente em alguns setores e indiretamente em outros.

No sentido que aqui se advoga, em nenhuma hipótese prega-se contra os avanços da ciência, da tecnologia e da tecnociência na produção de bens para a humanidade. O que se deseja salientar é o fato de que um segmento da ciência não pode, em nome da acumulação de bens, sobrepor-se às questões da proteção à vida em sentido lato, o que, em muitos casos, é assunto de pesquisa de outras áreas. Nesse sentido, Alves, Ribeiro e Rogers (2005) afirmam que é preciso agir de modo célere e eficaz não apenas para se corrigirem os malefícios ambientais, mas também para se evitarem novos danos à natureza, antecipando a afirmação de que é direito do ser humano desfrutar no presente e no futuro de um meio ambiente saudável, para que, em contrapartida, tenha mais saúde e qualidade de vida. Isso tudo evidencia o fato de que o meio ambiente pede socorro. Os recursos naturais 
são essenciais para a garantia da vida, seja humana, seja animal ou vegetal. Em sendo assim, há neste número da Revista Multitemas variados assuntos que, em vista da multi e interdisciplinaridade, podem colaborar de modo efetivo com a visão holística sobre a natureza.

Prof. Dr. Heitor Romero Marques

Editor-Chefe

\section{REFERÊNCIAS}

ALVES, D. L.; RIBEIRO, K. C. S.; ROGERS, P. As ciências ambientais na gestão dos recursos naturais. In: ENCONTRO NACIONAL SOBRE GESTÃO EMPRESARIAL E MEIO AMBIENTE (ENGEMA), 8., Rio de Janeiro. Anais [...]. Rio de Janeiro: ENGEMA, 2005.

CHASSOT, A. Ciência através dos tempos. 2. ed. São Paulo: Moderna, 1994.

CNPq. Tabela de Áreas do Conhecimento. Brasília, [s.d.]. Disponível em: http:// www.cnpq.br/documents/10157/186158/TabeladeAreasdoConhecimento.pdf. Acesso em: 24 fev. 2020.

KUHN, T. S. A estrutura das revoluções cientificas. São Paulo: Perspectiva, 1962.

PLATAFORMA SUCUPIRA. Qualis periódicos. Brasília, [s.d.]. Disponível em: https:// sucupira.capes.gov.br/sucupira/public/consultas/coleta/veiculoPublicacaoQualis/ listaConsultaGeralPeriodicos.jsf. Acesso em: 24. fev. 2020 
